\title{
HUBUNGAN PENDAMPING SUAMI DENGAN KALA DUA LAMA PADA IBU BERSALIN
}

\author{
Violita Siska Mutiara ${ }^{1}$, Elza Wulandari ${ }^{2}$, Ida Rahmawati ${ }^{3}$, Nidia Yusanty ${ }^{4}$ \\ Sarjana Terapan Kebidanan ${ }^{1,4}$, Diploma III Kebidanan ${ }^{2}$, Ilmu Keperawatan ${ }^{3}$ \\ STIKES Tri Mandiri Sakti Bengkulu \\ violitasiskamutiara@gmail.com¹,elzawulandari65@gmail.com²
}

\begin{abstract}
Psychological problems in mothers in the delivery room during childbirth are a level of anxiety that can cause labor to not progress, take longer, endanger the safety of the mother and her baby. Currently, support for husband's participation in reproductive health is still low, and there is a lack of support for the delivery process. The purpose of this study was to study the relationship between birth attendants and the second stage of delivery in mothers. The design of this research is analytical survey with cross sectional approach. The sample was 124 women who gave birth in the Sakura Room of Central Bengkulu Hospital in 2019, who were taken by total sampling. Collecting data in this study is using secondary data, and using a checklist and data collection format as a research instrument. The results showed that there was a significant relationship between a husband's companion at delivery and the incidence of the second period of delivery in mothers with $p=0.004$ $<0.005$. It is hoped that it can improve health services and appropriate screening for the incidence of the second period in laboring mothers, and present a husband as a labor companion.
\end{abstract}

Keywords $\quad$ : Birth Companion, Husband, Prolonged Second Stage Of Labor

\begin{abstract}
ABSTRAK
Permasalahan psikologis pada ibu di ruang bersalin pada saat melahirkan merupakan suatu tingkat kecemasan yang dapat menyebabkan partus tidak maju, memakan waktu yang lebih lama, membahayakan keselamatan ibu dan bayinya. Saat ini dukungan partisipasi suami dalam kesehatan reproduksi masih rendah, dan kurang dalam memberikan dukungan terhadap proses persalinan. Tujuan penelitian ini adalah untuk mempelajari hubungan pendamping persalinan dengan kala II lama pada ibu bersalin. Desain penelitian ini adalah Survey Analitik dengan pendekatan Cross Sectional. Sampelnya adalah ibu bersalin di Ruang Sakura RSUD Bengkulu Tengah Tahun 2019 sebanyak 124 orang, yang diambil secara total sampling. Pengumpulan data dalam penelitian ini yaitu menggunakan data sekunder, serta menggunakan checklist dan format pengumpulan data sebagai instumen penelitian. Hasil penelitian menunjukn bahwa terdapat hubungan signifikan antara pendamping suami saat persalinan dengan kejadian kala dua lama pada ibu bersalin dengan nilai $\mathrm{p}=$ $0,004<0,005$. Diharapkan agar dapat meningkatkan pelayanan kesehatan dan penapisan yang tepat terhadap kejadian kala dua lama pada ibu bersalin, serta hadirkan suami sebagai pendamping persalinan.
\end{abstract}

Kata Kunci : Pendamping Persalinan, Suami, Kala Dua Lama

\section{PENDAHULUAN}

Masalah kesehatan yang terjadi pada ibu selama proses persalinan idealnya dapat menimbulkan dampak yang dapat meluas ke berbagai aspek kehidupan. Dampak terburuk yang dapat dialami adalah kematian ibu. Hal ini merupakan salah satu parameter kemajuan bangsa dalam hal pelayanan kesehatan. WHO memperhitungkan bahwa setiap harinya di tahun 2017, sekitar 810 wanita meninggal pada masa kehamilan dan persalinan. Sekitar 295.000 wanita meninggal selama kehamilan dan persalinan. Mayoritas (94\%) dari semua kematian ibu terjadi di negara berpenghasilan menengah dan rendah. Rasio kematian ibu antara tahun 2000 hingga 2017 menurun sekitar 38\% di seluruh dunia (WHO, 2019). Partus lama merupakan salah satu penyebab tertinggi 
keempat kematian ibu. Secara global, partus lama dapat menyebabkan kematian ibu mencapai 8\% dan Inonesia mencapai 9\% (Yusmaharani, 2017). Salah satu faktor yang dapat dilakukan untuk mencegah terjadinya kala dua lama adalah dengan menghadirkan pendamping persalinan bagi ibu bersalin. Ibu yang akan menghadapi proses persalinan pada umumnya akan merasa takut, cemas, khawatir, dan merasa tidak siap yang berdampak pada kelancaran proses persalinannya. Perasaan ini tidak hanya timbul pada ibu primigravida saja, melainkan dapat pula timbul pada semua ibu hamil yang akan menghadapi persalinan.

Permasalahan psikologis pada ibu di ruang bersalin pada saat melahirkan merupakan suatu tingkat kecemasan yang tinggi, sehingga dapat menyebabkan partus tidak maju dan memakan waktu yang lebih lama, serta dapat membahayakan keselamatan ibu dan bayinya (Rohani, Saswita and Marisah, 2015). Pendamping persalinan ini akan bermanfaat dalam memberikan dukungan fisik dan mental pasien saat persalinan. Dukungan fisik yang diberikan dapat berupa genggaman tangan, sentuhan, pijatan, dan usapan pada bagian punggung hingga kaki ibu yang dirasa nyeri. Sedangkan dukungan mental dapat berupa memberikan support, doa, kata-kata sayang, dan juga motivasi. Dengan adanya dukungan tersebut, ibu bersalin akan merasa lebih tenang, aman, nyaman,

semangat, kecemasannya berkurang, dan mempercepat proses persalinan. Saat emosi ibu sedang dalam keadaan tenang dan nyaman, sel-sel sarafnya akan mengeluarkan hormone oksitosin. Akibatnya akan menyebabkan terjadinya kontraksi pada rahim dan berusaha untuk mengeluarkan bayi (Musbikin, 2008).

Kehadiran pendamping persalinan ini juga dapat meminimalisir terjadinya komplikasi selama persalinan, waktu yang dibutuhkan dalam menghadapi persalinan akan semakin pendek, kepuasan ibu semakin meningkat dalam pengalaman menghadapi persalinan, dapat menurunkan potensi persalinan dengan tindakan vacuum ekstraksi, forcep, dan sectio caesarea, mengurangi intensitas rasa nyeri, mengurangi penggunaan analgesic dan oksitosin, meningkatkan kesehatan mental, serta mencegah terjadinya depresi postpartum (Leahy-Warren, McCarthy and Corcoran, 2011). Sedangkan persalinan tanpa pendamping akan menimbulkan ketegangan dan berakibat gangguan his dan menghambat proses persalinan. Pendamping persalinan memgang peranan penting saat proses persalinan, karena dapat mengurangi kebutuhan obat analgesik saat persalinan berlangsung (Lailia and Nisa, 2014). Penelitian Yulizar \& Zuhrotunida (2018) menyatakan bahwa ada hubungan yang bermakna antara pendamping persalinan dengan lama kala II pada ibu bersalin di Klinik S Curug Kabupaten Tangerang Tahun 2017. Ibu bersalin yang tidak didampingi selama proses persalinan berpeluang $10 \mathrm{kali}$ mengalami kala II memanjang dibandingkan dengan yang di dampingi. Penelitian serupa dilakukan (Untari and Astarina, 2017) yang menyatakan bahwa ada hubungan antara pendampingan suami dengan lama kala II persalinan.

Hasil pencatatan rekam medik di RSUD Dr.M.Yunus Provinsi Bengkulu pada tahun 2018 terdapat kasus kala II lama pada ibu bersalin sebanyak 20 kasus dari 273 persalinan spontan dan tahun 2019 sebanyak 3 kasus dari 324 persalinan spontan. Sedangkan hasil pencatatan di RSUD Bengkulu Utara, kejadian kala II lama pada tahun 2018 sebanyak 62 kasus dari 272 persalinan spontan dan tahun 2019 sebanyak 78 kasus dari 328 persalinan spontan. Dan hasil pencatatan di RSUD Bengkulu Tengah, kejadian kala II lama pada tahun 2018 sebanyak 30 kasus dari 98 persalinan spontan dan pada tahun 2019 sebanyak 35 kasus dari 124 persalinan spontan. Hal ini menunjukkan 
bahwa masih cukup tingginya kasus kala II lama di wilayah Bengkulu, khususnya di RSUD Bengkulu Tengah.

RSUD Bengkulu Tengah merupakan salah satu RSUD yang mendukung dan memberikan izin bagi suami dan keluarga untuk mendampingi ibu bersalin dalam proses persalinannya. Hal ini dapat dilihat dari hasil pencatatan proses persalinan dan partograf di Ruang Sakura. Salah satu tujuannya adalah untuk membuat ibu bersalin menjadi lebih tenang dan rileks, sehingga proses persalinan pun dapat berlangsung lebih cepat. Dengan demikian, kehadiran suami dan keluarga dalam mendampingi proses persalinan sangat diperlukan untuk menurunkan angka kejadian partus lama ini.

Berdasarkan hasil survey awal yang dilakukan pada tanggal $20-27$ desember 2019 di Ruang Persalinan RSUD Bengkulu Tengah, dari 5 orang ibu bersalin terdapat 3 orang ibu bersalin yang didampingi oleh suaminya. Lama kala II ketiga ibu tersebut masing-masing berlangsung selama 45 menit, 54 menit, dan 48 menit. Sedangkan 2 orang ibu bersalin lainnya tidak didampingi oleh suami/keluarganya. Lama kala II kedua ibu tersebut yaitu 60 menit dan 50 menit.

\section{METODE}

Penelitian ini telah dilakukan di Ruang Sakura RSUD Bengkulu Tengah dan dilaksanakan pada tanggal. 7 - 14 Juli 2020. Penelitian ini menggunakan desain penelitian Survey analitik dengan pendekatan pendekatan Cross Sectional. Populasi dalam penelitian ini adalah seluruh ibu bersalin pervaginam di Ruang Sakura RSUD Bengkulu Tengah Tahun 2019 yaitu berjumlah 124 orang. Teknik pengambilan sampel dalam penelitian ini dilakukan secara Total Sampling, yaitu prosedur mengambil sampel yang besarnya sama dengan besar populasinya, yaitu berjumlah 124 orang ibu bersalin. Jenis data yang akan dikumpulkan dalam penelitian ini merupakan data sekunder, yaitu data hasil pencatatan proses persalinan dan partograf di ruang kebidanan. Intrumen pengumpulan data menggunakan check list. Analisis data dengan menggunakan analisis univariat dan bivariat dengan uji statistik uji chi square.

\section{HASIL}

\section{Analisis Univariat}

Analisis univariat dibutuhkan untuk mengetahui gambaran dari masing-masing variabel, baik variabel bebas maupun variabel terikat dengan menggunakan persentase. Hasil analisisnya adalah sebagai berikut.

Tabel 1. Distribusi kala dua lama pada Ibu bersalin di Ruang Sakura RSUD Bengkulu Tengah

\begin{tabular}{lcc}
\hline Persalinan & Frekuensi & $\begin{array}{c}\text { Persen } \\
\text { tase } \\
(\mathbf{\%})\end{array}$ \\
\hline Kala dua Lama & 35 & 28,2 \\
Tidak Kala & 89 & 71,8 \\
duaLama & & \\
\hline Total & 124 & $100 \%$ \\
\hline
\end{tabular}

Berdasarkan tabel 1 dapat diketahui bahwa ibu bersalin di Ruang Sakura RSUD Bengkulu Tengah sebagian kecil $(28,2 \%)$ mengalami Kala duaLama dan sebagian besar $(71,8 \%)$ tidak mengalami kala dua lama.

Tabel 2. Distribusi frekuensi pendamping suami pada Ibu Bersalin di Ruang Sakura RSUD Bengkulu Tengah tahun 2019

\begin{tabular}{lcc}
\hline \multicolumn{1}{c}{$\begin{array}{c}\text { Pendamping } \\
\text { Persalinan }\end{array}$} & $\begin{array}{c}\text { Frekuen } \\
\text { si }\end{array}$ & $\begin{array}{c}\text { Perse } \\
\text { ntase } \\
(\%)\end{array}$ \\
\hline Tidak didampingi & 58 & 46,8 \\
suami & 66 & 53,2 \\
$\begin{array}{l}\text { Didampingi } \\
\text { suami }\end{array}$ & & \\
\hline Total & 124 & $100 \%$ \\
\hline
\end{tabular}

Berdasarkan tabel 2 dapat diketahui bahwa ibu bersalin di Ruang Sakura RSUD Bengkulu Tengah Tahun 2019 sebagian kecil $(46,8 \%)$ mengalami tidak didampingi suami dan sebagian besar 
$(53,2 \%)$ tidak didampingi suami.

\section{Analisis Bivariat}

Analisis bivariat dilakukan untuk melihat hubungan antara variabel independen (pendamping persalinan) terhadap variabel dependen (kala II lama). Dalam penelitian ini menggunakan analisis bivariate menggunakan uji chisquare $\left(x^{2}\right)$. Hasil analisisnya adalah sebagai berikut.

Berdasarkan Tabel 3 dapat diketahui bahwa kejadian kala dua lama pada ibu bersalin di Ruang Sakura RSUD Bengkulu Tengah sebagian besar $(41,4 \%)$ dialami oleh ibu bersalin tidak didampingi oleh suami dan sebagian kecil $(16,7 \%)$ dialami oleh ibu bersalin yang didampingi oleh suami. Sedangkan ibu bersalin yang tidak mengalami kala dua lama sebagian besar didampingi oleh suami $(83,3 \%)$ dan sebagian kecil $(58,6 \%)$ tidak didampingi oleh suami.

Hasil analisis Chi-Square menunjukkan bahwa nilai $\rho<(0,05)$ yang artinya ada hubungan yang bermakna antara adanya pendamping persalinan dengan kejadian kala dua lama pada ibu bersalin. Dilihat dari nilai risiko OR 3,529 artinya ibu bersalin yang tidak didampingi oleh suami berisiko mengalami kala dua lama sebesar 3,529 kali dibandingkan dengan ibu bersalin yang didampingi oleh suami. Selain itu, dari hasil analisis Contingency Coeffecient diperoleh nilai $\rho$ $=0,004<(0,05)$ yang artinya terdapat korelasi antara pendamping suami saat persalinan dengan kejadian kala dua lama pada ibu bersalin.

Tabel 3. Hubungan Pendamping Persalinan dengan Kejadian Kala II Lama pada Ibu Bersalin di RSUD Bengkulu Tengah Tahun 2019

\begin{tabular}{|c|c|c|c|c|c|c|c|c|c|c|}
\hline \multirow[t]{3}{*}{$\begin{array}{l}\text { Pendamping } \\
\text { Persalinan }\end{array}$} & \multicolumn{4}{|c|}{$\begin{array}{l}\text { Kejadian Kala II } \\
\text { Lama }\end{array}$} & \multicolumn{2}{|c|}{ Total } & \multirow[t]{3}{*}{$\mathrm{P}$} & \multirow[t]{3}{*}{ OR } & \multicolumn{2}{|c|}{$\begin{array}{c}\text { Contingency } \\
\text { Coefficient }\end{array}$} \\
\hline & \multicolumn{2}{|c|}{ Kala II Lama } & \multicolumn{2}{|c|}{$\begin{array}{c}\text { Tidak Kala II } \\
\text { Lama } \\
\end{array}$} & \multirow[t]{2}{*}{$\mathrm{F}$} & \multirow[t]{2}{*}{$\%$} & & & \multirow[t]{2}{*}{$\mathrm{C}$} & \multirow[t]{2}{*}{$\mathrm{P}$} \\
\hline & $\mathrm{f}$ & $\%$ & $\mathrm{f}$ & $\%$ & & & & & & \\
\hline $\begin{array}{l}\text { Tidak } \\
\text { Didampingi }\end{array}$ & 24 & 41,4 & 34 & 58,6 & 58 & 100 & 0,004 & 3,529 & 0,264 & 0,002 \\
\hline Didampingi & 11 & 16,7 & 55 & 83,3 & 66 & 100 & & & & \\
\hline Jumlah & 35 & 28,2 & 89 & 71,8 & 124 & 100 & & & & \\
\hline
\end{tabular}

\section{PEMBAHASAN}

Berdasarkan hasil penelitian yang dilakukan di ruang Sakura RSUD Bengkulu tengah tahun 2019, dapat diketahui bahwa dari 124 orang ibu bersalin terdapat 35 orang $(28,2 \%)$ yang mengalami kala dua lama dan 89 orang $(71,8)$ tidak mengalami kala dua lama. Penyebab terjadinya kala dua lama adalah 5P, yaitu Power yang merupakan tenaga dan kekuatan yang berasal dari ibu saat mengedan, serta his dan kontraksi otototot uterus yang dapat menyebabkan bayi segera lahir. Jika ada kelainan pada tenaga ini, maka dapat menyebabkan kemacetan atau memanjangnya lama waktu kala II. Kelainan ini pada umumnya berupa his yang tidak adekuat/lemah, his tidak teratur, intervalnya lama, dan lemahnya tenaga ibu saat mengejan. Passanger (Bayi) yang meliputi kelainan sikap janin, ukuran kepala, letak, presentasi, posisi janin, dan berat badan janin. Passage (jalan lahir) yang meliputi ukuran rongga panggul yang sempit, otot-otot yang kaku, dan bentuk yang tidak sempurna. Psikologi Ibu yang berupa dukungan mental dan psikis pada ibu. Salah satunya dengan kehadiran suami sebagai pendamping persalinan. Penolong persalinan yang memiliki pengetahuan dan 
kompetensi dapat memberikan asuhan yang sesuai pada ibu bersalin. Jika terjadi kelainan pada kelima faktor ini maka dapat menyebabkan lama proses persalinan akan memanjang dan semakin lama. Akibatnya akan terjadi komplikasi yang dapat membahayakan ibu dan janin (Yulianti et al, 2014). Secara umum, saat proses persalinan perlu dilakukan pendampingan oleh suami.

Berdasarkan hasil penelitian diketahui dari 124 orang ibu bersalin terdapat 66 orang $(53,2 \%)$ yang didampingi suami dan 58 orang 946,8\%) tidak didampingi oleh suami. Bagi ibu bersalin yang tidak didampingi oleh suami, selama persalinannya didampingi oleh ibunya (27 orang), mertua (10 orang), kaka (3 orang), nenek (3 orang), dan tidak didampingi sama sekali (3 orang). Kehadiran suami akan memberikan dukungan psikis secara positif bagi istri yang akan melahirkan (Musbikin, 2015). Dengan demikian selama masa kehamilan, seorang suami juga harus menyiapkan diri dalam menghadapi persalinan istrinya. Karena saat ini dukungan partisipasi suami dalam kesehatan reproduksi masih rendah, dan kurang dalam memberikan dukungan terhadap proses persalinan. Faktor tersebut dapat dipengaruhi oleh pengetahuan, status perkawinan, sosial ekonomi budaya, dan pendidikan suami (Sari, 2018).

Ruang persalinan RSUD Bengkulu Tengah, pendamping persalinan pada umumnya adalah suami, namun beberapa pasien juga ada yang didampingi oleh keluarganya. Dalam hal ini pendamping persalinan diperkenankan masuk ke dalam ruangan persalinan, mendampingi $\mathrm{ibu}$ bersalin, serta memberikan dukungan secara fisik dan psikis di sisi ibu selama proses persalinan berlangsung. kehadiran pendamping persalinan ini sangat bermanfaat bagi proses persalinan, diantaranya yaitu memberi rasa tenang, menguatkan psikis ibu, menghindari stress, dan memberikan pengaruh positif secara psikis; selalu ada jika dibutuhkan; menguatkan kedekatan emosi antara suami dan istri; menumbuhkan naluri seorang ayah; suami akan lebih menghargai istri; menurunkan tingkat kecemasan ibu; mengurangi rasa nyeri; mempermudah dan mempercepat proses persalinan; menghindari komplikasi dan penyulit pada persalinan; serta mencegah terjadinya bayi asfiksia (Hasanah, 2018).

Hasil analisis Chi-Square menunjukkan bahwa nilai $\rho<(0,05)$ yang artinya ada hubungan yang bermakna antara pendamping persalinan dengan kejadian kala II lama pada ibu bersalin. Dilihat dari nilai risiko OR 3,529 artinya ibu bersalin tidak didampingi oleh suami berisiko mengalami kala II lama sebesar 3,529 kali dibandingkan dengan ibu bersalin yang didampingi oleh suaminya. Selain itu, dari hasil analisis Contingency Coeffecient diperoleh nilai $\rho<(0,05)$ yang artinya terdapat korelasi antara pendamping persalinan dengan kejadian kala II lama pada ibu bersalin. Dilihat dari nilai $\mathrm{C}$ menunjukkan angka 0,264 artinya korelasi antara usia ibu dengan kejadian preeklamsi pada ibu bersalin lemah. Hal ini disebabkan karena adanya faktor lain yang juga berpengaruh terhadap kejadian kala II lama ini, yaitu dapat disebabkan karena usia < 20 dan > 35 tahun, paritas (primi dan grande), usia kehamilan (posterm), KPD, KEK, anemia, bb bayi > 4000, tinggi ibu $<150 \mathrm{~cm}$, serta his dan tenaga ibu yang lemah.

Masysanto (2012) menyatakan bahwa selama proses persalinan, ibu akan mengalami rasa nyeri akibat adanya kontraksi uterus yang menyebabkan terjadinya dilatasi dan pendataran serviks. Ibu juga akan merasa cemas dan takut dalam menghadapi persalinan ini. Adanya kecemasan pada ibu bersalin ini dapat berdampak terhadap meningkatnya sekresi hormone adrenalin dan ACTH (Adenocorticotropic hormone). Salah satu efek adanya peningkatan hormone adrenalin ini adalah adanya konstriksi pembuluh darah sehingga 
menyebabkan suplai oksigen ke janin akan menurun. Penurunan aliran darah ini juga dapat menyebabkan melemahnya kontraksi uterus dan berakibat memanjangnya proses persalinan dan proses persalinan akan memakan waktu yang lebih lama. Sedangkan peningkatan ACTH dapat menyebabkan peningkatan kadar kortisol serum dan gula darah. Sejalan dengan Wijaya, Wandini, \& Wardiyah (2014) yang menyatakan bahwa terdapat pengaruh pendampingan persalinan terhadap lama proses persalinan kala II di Ruang Delima RSUD dr.H.Abdul Moeloek Provinsi Lampung. Rata-rata lama persalinan kala II responden yang didampingi suami lebih cepat dibandingkan dengan yang tidak didampingi suami.

Uraian diatas dapat diketahui bahwa kehadiran suami sebagai pendamping persalinan sangat berpengaruh sekali terhadap jalannya proses persalinan, khususnya dalam mempercepat lama kala II. Kehadiran suami dapat mengurangi rasa kecemasan pada ibu bersalin di saat menghadapi persalinan, sehingga dapat menyebabkan emosi ibu akan menjadi lebih stabil, lebih tenang, merasa senang, nyaman, dan rileks, serta menambah semangat dan kepercayaan diri pada ibu bersalin untuk mengedan dan akhirnya mempercepat proses persalinan kala II. Terbukti dari hasil penelitian ini didapatkan kejadian kala II lama sebanyak $41,4 \%$ dialami oleh ibu bersalin yang tidak didampingi oleh suaminya. Oleh sebab itu, sangat disarankan bagi suami untuk mendampingi istrinya selama proses persalinan.

\section{KESIMPULAN}

Terdapat hubungan antara pendamping persalinan dengan kejadian kala II lama pada ibu bersalin di Ruang Sakura RSUD Bengkulu Tengah Tahun 2019. Kehadiran suami akan memberikan dukungan psikis secara positif bagi istri yang akan. Dengan demikian selama masa kehamilan, seorang suami juga harus menyiapkan diri dalam menghadapi persalinan istrinya

\section{UCAPAN TERIMAKASIH}

Terimakasih kepada lokasi penelitian, responden, STIKES Tri Mandiri Sakti, para penilis penelitu, serta pihak-pihak yang telah banyak membantu dan berkontribusi dalam terselesaikannya penelitian ini.

\section{DAFTAR PUSTAKA}

Hasanah, M. (2018) 'Pengaruh pendampingan suami terhadap pengurangan rasa cemas pada proses persalinan ibu primigravida kala I di klinik pratama jannah medan tembung', Politeknik Kesehatan Kemenkes RI Jurusan Kebidanan Medan Prodi D-IV Kebidanan. Medan, pp. 1-76.

Lailia, I. N. and Nisa, F. (2014) 'Pendampingan suami terhadap kelancaran proses persalinan di BPM Arifin S Surabaya'. Surabaya: UNUSA, FKK, Prodi D III Kebidanan. Available at: http://library1.nida.ac.th/termpaper6/s d/2554/19755.pdf.

Leahy-Warren, P., McCarthy, G. and Corcoran, P. (2011) 'Postnatal Depression in First-Time Mothers: Prevalence and Relationships Between Functional and Structural Social Support at 6 and 12 Weeks Postpartum', Archives of Psychiatric Nursing. Elsevier Inc., 25(3), pp. 174-184. doi: 10.1016/j.apnu.2010.08.005.

Masysanto, A. (2012) 'Pengaruh pendampingan persalinan terhadap lama persalinan di RSUD kota surakarta', UNS. Surakarta: Program Studi D-IV Kebidanan Fakultas Kedokteran Universitas Sebelas Maret 
Surakarta, pp. 1-25.

Musbikin, I. (2008) Panduan Ibu Hamil Dan Melahirkan. Yogyakarta: Mitra Pustaka.

Rohani, Saswita, R. and Marisah (2015) Asuhan Kebidanan pada Masa Persalinan. Jakarta: Salemba Medika.

Sari, W. N. I. (2018) 'Hubungan dukungan suami dengan tingkat kecemasan menghadapi persalinan pada ibu hamil primigravida trimester III di puskemas Mlati II Sleman'. Yogyakarta: Universitas 'Aisyiyah Yogyakarta.

Untari, S. and Astarina, R. (2017) 'Hubungan pendampingan suami dengan lama persalinan kala II di puskesmas grobogan pada tahun 2017', The Shine Cahaya Dunia Kebidanan, 3(1).

WHO (2019) Maternal mortality, WHO. Available https://www.who.int/news-room/factsheets/detail/maternal-mortality (Accessed: 10 January 2020).

Wijaya, D. E., Wandini, R. and Wardiyah, A. (2014) 'Effect of the Length of Assistance Husband in the Delivery Stage II Delima Hospital', Jurnal Keperawatan, 13(12), pp. 6-14.

Yulianti, L., Maemunah, Susilawati, L. and Rukiah, A. Y. (2014) Asuhan Kebidanan II (Persalinan). Jakarta: Trans Info Media.

Yulizar and Zuhrotunida (2018) 'Hubungan pendamping persalinan dengan lama kala II', Jurnal JKFT: Universitas Muhammadiyah Tangerang, 3(Januari-Juni), pp. 8693.

Yusmaharani (2017) 'Hubungan paritas dan usia ibu bersalin dengan kejadian partus lama', JOMIS (Journal of Midwifery Science), 1(1), pp. 35-40. 